\title{
The government medical service and British missions in colonial Malawi, c. 1891-1940: crucial collaboration, hidden conflicts
}

\author{
Markku Hokkanen
}

As Megan Vaughan has pointed out, for most of the colonial period in Africa, Christian missions 'provided vastly more medical care than did colonial states'. ${ }^{1}$ Indeed, from the outset of European colonial rule, most imperial states left the provision of the majority of education and healthcare to Christian missions. ${ }^{2}$

In colonial Malawi, missionary medicine preceded British rule by nearly two decades, making it a crucial site for investigating relations and interactions between missions and the state. ${ }^{3}$ As Vaughan and others have shown, there were notable differences as well as common ground between missionary and secular discourses of African illnesses and Western medicine in colonial Africa. ${ }^{4}$ The focus of this chapter is on the connections and exchanges that took place within the realms of medicine and public health between the colonial administration (particularly its medical department) and the British missions of Livingstonia, Blantyre and the Universities' Mission to Central Africa (UMCA). ${ }^{5}$

In his assessment of the early colonial medical service in Malawi, Colin Baker presents a generally sympathetic account of an underresourced medical department that gradually expanded its services to the African population and provided a form of public medical service to colonial subjects (before the National Health Service had been established in Britain). ${ }^{6}$ By contrast, Charles Good's more recent appraisal of colonial medicine in Malawi is highly critical. Notably, in discussing the reasons for this, Good highlights the colonial government's limited cooperation and support for missionary medicine, arguing that formal collaboration between the two groups was largely limited to the treatment of leprosy patients. ${ }^{7}$

In order to better understand the contexts in which Western 
medicine was practised in British Africa, both formal and informal modes of cooperation (and conflict) must be examined. ${ }^{8}$ This chapter discusses the ties that connected missionary physicians and the Colonial Medical Service: public health campaigns, the division of labour, the exchanges of knowledge and materials and issues raised surrounding the ownership of African medical education. Western medical practice in Malawi has largely been viewed as dominated by missionary physicians until the First World War, after which government medical services became increasingly prominent. While this overview is generally accurate, it over-simplifies the reality that witnessed a long history of many connections, relations and exchanges between government and mission medicine. This chapter seeks to explore these relations and interactions in order to illustrate the formal and informal forms of cooperation, contestation and conflict. Despite many differences, colonial and missionary medicine were intertwined, with each benefitting from the other's cooperative co-existence.

\section{Missions and colonial administration}

The first permanent mission in Malawi was the Free Church of Scotland's Livingstonia Mission. Livingstonia's first medical missionary, Robert Laws, arrived with the pioneer party in 1875. Laws, a qualified doctor, headed the mission for many years and became a respected missionary statesman: his voluminous correspondence remains a valuable source for investigations into mission-government relations. ${ }^{9}$ The second permanent missionary establishment in Malawi was the Blantyre Mission of the Church of Scotland, founded in 1876 in the Shire Highlands. Significantly, both Scottish missions referred to their doctors as Medical Officers, a practice which was to be adopted by most government medical services in Africa, emphasising their official authority. The English Anglican Universities' Mission to Central Africa (UMCA) returned to Malawi in 1882 (after its first failed attempt in the 1860s), and established a station on Likoma Island near the eastern shore of the Lake Malawi. ${ }^{10}$ In 1900, both the UMCA and Livingstonia operated across areas that were both on and beyond the borders of the fledgling British Central Africa Protectorate. Both held a practical monopoly over the practice of Western medicine in their respective borders. ${ }^{11}$ By contrast, the Blantyre mission concentrated its work at the heart of the new protectorate in the southern region of Malawi.

The Scottish missions and churches played a crucial part in lobbying for the establishment of a British Protectorate over the Lake Nyasa region. ${ }^{12}$ After the establishment of the Protectorate, the Blantyre 
Mission in particular clashed with Harry Johnston's administration. Missionaries criticised Johnston's military campaigns against African rulers, his often brutal methods of tax collection and the treatment of Africans more generally under his tenure. The missionaries at Blantyre also pointed out that the general population received little in return for their tax and labour contributions. They pressed the government to give greater medical attention to Africans. ${ }^{13}$

Johnston had set out to establish the British Protectorate in Central Africa with meagre resources, initially funded by Cecil Rhodes's British South Africa Company. In the early 1890s the British Central Africa Protectorate was established through a series of treaties and 'small wars'. ${ }^{14}$ Johnston's administration employed only a handful of doctors. In 1891, the entire medical services budget was £250 - less than the salary of a single Scottish missionary doctor. The first permanent government Medical Officer (MO), Wordsworth Poole, set up his practice in Zomba, the new capital, in 1895. Mortality rates for MOs were high in the 1890s: by 1901 four government doctors had died. Nevertheless, medical personnel were still recruited to the region and by 1910 the annual budget allocated to the medical department had increased to $£ 9,000$. On the back of these funds, the government established its main hospital in Zomba. ${ }^{15}$ Despite relatively meagre resources, the medical department was the second largest of the colonial administration, with government medical practitioners largely operating in the Shire Highlands and lower Shire river region. ${ }^{16}$ By the First World War, the Colonial Medical Service had considerably expanded its services in the southern part of the country, which represented the hub of the colonial economy.

The government first began to support missionary medicine in Blantyre, where a major mission hospital, St Luke's Hospital, was established in the late 1890s. In the early 1900s, the government funded two of the hospital's beds (at the cost of £20 per annum). In 1906 the government additionally gave $£ 50$ to support five beds in a smaller mission hospital in Zomba, and two years later this hospital was put under government control, most likely because it was deemed more fitting to have a government-run hospital in the capital. ${ }^{17}$ Nevertheless the Blantyre Mission continued to dominate medical services for Africans in the commercial centre of the Protectorate. In 1939, the government paid an annual subsidy of $£ 600$ to the Blantyre hospital. During the interwar period, the Church of Scotland mission also received payment for the upkeep of its Asiatic Hospital in Blantyre. ${ }^{18}$

As in other African colonial territories, before the First World War, the tiny Colonial Medical Service in Malawi focused its efforts on the health of government employees and on high-profile campaigns against 
major epidemic diseases. During this period, missions clearly remained the primary source of Western medicine for the majority of the African population. ${ }^{19}$

In terms of in-patient numbers, St Luke's hospital in Blantyre was by far the largest hospital in Malawi for most of the early colonial period: as early as 1897 over 300 patients were admitted. This popularity grew, with hospital records for 1903 indicating that over 800 in-patients were treated during that year. ${ }^{20}$ Similarly, between 1904 and 1911, the UMCA hospital in Likoma was the second largest hospital in Malawi. In the north, the central hospital in Livingstonia became a major regional healthcare facility during the 1910s and 1920s. ${ }^{21}$

Perhaps unsurprisingly, in the Shire Highlands, missionary medicine tended to focus on African male workers. A clear majority of the early in-patients at Blantyre were male. As Rennick has argued, the colonial settlers became important 'refereeing agents' for the Blantyre hospital, and mission medicine took on an active role in the control and examination of African labour. Many of those treated were migrant labourers. The administration also became a referring agent for mission hospitals: in Blantyre in the early 1900s and in Zomba between 1903 and $1908 .^{22}$

African patients were frequently referred to mission hospitals by government agents. There were fewer recommendations from missions to send patients to colonial hospitals, with the notable exception of those who were deemed to be 'lunatics'. The history of the movement of the insane is indicative of broader moral concerns over offering faithbased care to members of society deemed socially problematic. Since the early 1900s missions had strongly pressed the government to establish an asylum in the territory, a request that was realised only in 1910 with the establishment of the poorly resourced Zomba Asylum (1910), which was initially part of the Central Prison. Even after the establishment of this asylum, however, it was evident that missionaries wanted 'incurable' cases to be taken care of by the state, thus removing problematic elements of society from mission communities. In 1913, Laws told the Legislative Council that he spoke for all medical missionaries when he expressed relief that there was now a place to which dangerous cases could be sent. Furthermore, the mission connection with the Zomba Asylum undoubtedly contributed to the way in which secular colonial medicine assessed African insanity. In 1935, Nyasaland MOs Shelly and Watson concluded in their study of Zomba inmates that increasing contact with civilisation, education and Christianity was dangerous for African mental health, thereby inferring (among other things) that is was better that the African insane were removed from missionary influences. ${ }^{23}$ 
Government medical services expanded considerably during the interwar years. In 1921, the government medical staff treated 19,000 African cases; and by 1937, 729,000 cases were treated, with medical expenditure increasing to $£ 53,000$ in $1938 .{ }^{24}$ Despite this expansion, the Director of Medical and Sanitary Services reported in 1939 that 'the Medical Department has not yet been able to make contact with the African population in the full measure necessary to gain its confidence'. In the 1930s, government services were still very much focused on the southern part of the Protectorate. ${ }^{25}$ In many rural areas, mission hospitals and dispensaries remained the only scattered outposts of Western medicine.

Indeed, so scarce were government medical facilities in rural areas that missionary doctors were informally relied upon to treat government officials and their families when they were posted to, or travelling in, remote areas. This trend was regarded as significant enough to warrant an appeal in 1923 from the Nyasaland government to the Colonial Office to put in place more formal procedures to allow the Governor to pay non-official doctors for the treatment of officers at remote outstations. ${ }^{26}$ Illustratively, in 1925, the Indian Sub-Assistant Surgeon in charge of the government hospital at Mzimba, Northern Province, suffered a stroke and was taken to the nearest doctor, Agnes Fraser (Livingstonia) at Loudon. ${ }^{27}$

Occasionally, doctors and nurses moved from mission to government service. ${ }^{28}$ For ambitious mission doctors, colonial medical posts could offer research opportunities and contractual perks, but movements of personnel were also motivated by personal frustration or by conflicts within the missions. ${ }^{29}$ In 1897, for example, David Kerr Cross of Livingstonia switched to a government post, a move that took place against a backdrop of enduring tensions and conflicts within his mission. Sir Harry Johnston clearly appreciated Cross's change of allegiance, and quoted him as a medical expert in his book, British Central Africa. ${ }^{30}$

Similarly, in 1903, Samuel Norris of the Blantyre Mission joined the Colonial Medical Service. Norris was at least partly motivated by a desire to spend more time researching tropical medicine, having been clearly dissatisfied with the opportunities presented by his position in Blantyre. According to Rennick, Norris 'never fully internalised and fulfilled the evangelical aspects of the medical missionaries' role $^{\prime}{ }^{31}$

Despite these cases, however, there was relatively little mobility of doctors between mission and government service. Mission and government doctors in Malawi were largely distinct groups, which were nevertheless connected through the British medical profession, education and the small elite circles within which Europeans in the Protectorate 
operated. From 1926 onwards, mission and government doctors met regularly at meetings of the Nyasaland Medical Council. Officially at least, cooperation was regarded as a success, with the Director of Medical Services (DMS) admitting in 1940 that, through advice and cooperation, the missionaries had 'helped to shape the medical policy of the country'. ${ }^{32}$

As Baker points out, the 1906 Registration of Medical Practitioners Ordinance of Nyasaland was 'highly biased' towards British qualifications. ${ }^{33}$ An early exception to the rule was Daniel Malekebu of the Providence Industrial Mission (PIM), a Malawian who had obtained his medical qualifications in the United States. Malekebu was viewed with some suspicion by the authorities, probably because his mission had been at the heart of the Chilembwe Rising in 1915. In 1927, Malekebu's status as a mission doctor was considered by the highest levels of the colonial government, with the Executive Council ultimately agreeing that he was eligible for registration under the Ordinance. ${ }^{34}$ Simply put, the colonial medical department tacitly recognised the medical work of the three major British missions. By 1940, the Dutch Reformed Church and Seventh Day Adventists were also acknowledged for their medical facilities, although the Catholic missions and Malekebu's PIM were not. 35

The important question of the extent to which Malawians themselves differentiated between colonial and missionary medicine is beyond the scope of this chapter. ${ }^{36}$ However, it seems that in the early colonial period, and in village communities with little direct contact with hospitals or dispensaries, Western medicine was generally categorised as a medicine of the whites (mankhwala achizungu in chiChewa). Among those with direct experience of Western medicine, people quickly formed opinions about medical personnel and hospitals: by the interwar period, Malawians spoke dismissively of 'boys' medi-

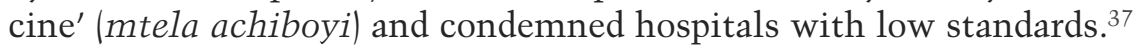
In the end, whether delivered by representatives of the Church or the state, assessments of Western medicine crucially depended on African patients' experiences of the healing skills of the medical personnel, expressions of goodwill and the cost of treatment.

\section{Cooperation in epidemics: smallpox, sleeping sickness, bubonic plague}

Epidemic diseases required a coordinated response from missions and the administration. In the Shire Highlands, Blantyre Mission and the government were united in their goal of protecting the region from epidemics that were a threat to Africans and Europeans alike. The 
oldest of the major epidemic diseases was smallpox, which had been known and feared in South-Central Africa in the pre-colonial era. In the Shire valley at least, variolation was practised in the nineteenth century before the arrival of Europeans, demonstrating that the principle of vaccination was not alien to local societies. ${ }^{38}$ In any case, it is certain that missionaries introduced Western vaccination to Malawi before the establishment of colonial rule, with evidence showing that Laws had access to a supply of lymph as early as 1875 , and that by 1883 vaccinations had been carried out in both Livingstonia and Blantyre. ${ }^{39}$

Smallpox vaccination was one of the most efficient tools in demonstrating efficacy that early missionary and colonial doctors possessed. Correspondingly, it was much sought after. In Northern Ngoniland, for example, it was one form of Western medicine for which people were eagerly willing to pay, even though the process of vaccinations was often hindered by the failure of the lymph supply. ${ }^{40}$ Furthermore, largescale campaigns required vaccinators, and at the turn of the century missions could provide the crucial African and European personnel that the government lacked.

In the Shire Highlands, the initiative for collaborative vaccination campaigns came from the Blantyre Mission, where Neil Macvicar had established a dynamic central hospital and a ground-breaking training programme for African medical assistants. The government MOs joined the campaign in 1899. Blantyre had trained African vaccinators and medical assistants, such as Harry Kambwiri, who for their part enabled the vaccination of tens of thousands of people in the Shire Highlands. By 1903, smallpox prevention measures in Southern Malawi were deemed largely successful. The colonial administration gave full credit to medical missionaries for this evident success, and especially to the Blantyre Mission (which had reportedly vaccinated 60,000 people in the Blantyre district between 1900 and 1902). ${ }^{41}$ For its part, the UMCA was also important within the history of vaccination provision in Malawi, especially in the border zone between the British Protectorate and German East Africa (1899-1900). ${ }^{42}$

After smallpox epidemics reoccurred in 1908, the administration issued a Vaccination Ordinance, which imposed compulsory vaccination and prohibited variolation. It appeared that implementation of this ordinance relied upon the successful cooperation between faith-based and secular medical groups. In the Legislative Council, Alexander Hetherwick of Blantyre heartily advocated compulsory vaccination, praised mission-government cooperation and voiced suspicions that the medical department had been rather lax over recent vaccinations - a charge vigorously denied by the Deputy Governor. Certainly, the government and missions carried out extensive public vaccination 
programmes: between 1911 and 1913 over 380,000 individual vaccinations were reported. The Principal Medical Officers (PMOs) believed that the vaccination campaigns had effectively eradicated smallpox. However, Rennick has pointed out more recently that the reduction may have been due to changes in smallpox epidemiology, and that the statistics may have been incorrect, as their compilation was unreliable. ${ }^{43}$

From this emerging picture, it is clear that the contributions of missions were crucial to the implementation of the vaccination campaigns: missions provided skilled personnel and enabled colonial medical services to reach districts where there was no official presence. Furthermore, in established areas the missionaries and their African associates had intimate knowledge of local conditions and were known by the local population. For the government, vaccination campaigns were cost-effective: in 1913, the PMO reported that the medical department had spent the relatively meagre sum of $£ 200$ to pay 'Native Vaccinators' and a further $£ 100$ for the lymph supply. ${ }^{44}$

For missionaries, cooperation with the government generated goodwill. They received more resources and the backing of the colonial state to carry out large-scale vaccinations, which in turn extended the medical missions' evangelistic reach. It is evident that the missions used vaccination campaigns for their own religious ends. For example, at Bandawe station in 1900, one Livingstonia evangelist and medical assistant preached to the people who had gathered to be vaccinated, emphasising through the power of analogy that Christianity offered protection against 'the disease of $\sin$ in the heart'. ${ }^{45}$ The early vaccinators were mostly mission-educated men; probably many of them were also Christian teachers, church elders and evangelists. It is possible that they carried out evangelisation whilst employed by the government. Many vaccinators worked in remote districts without European supervision. ${ }^{46}$ In 1902, Laws reported to PMO Hearsey that he had sent two Livingstonia 'lads' to carry out vaccinations amongst the Senga. In 1906, Hearsey sent lymph to all eight Livingstonia doctors. Livingstonia doctors in Northern Rhodesia also took part in vaccination campaigns. ${ }^{47}$ In Malawi, government and mission cooperation in vaccination continued at least into the 1940s. ${ }^{48}$

Some similarities in this spirit of informal cooperation can be seen in approaches to sleeping sickness epidemics. In 1907, James Chisholm (Livingstonia) in Mwenzo, North Rhodesia examined a blood sample taken from a dying patient who had arrived from the Belgian Congo. Chisholm diagnosed a case of sleeping sickness, which was to become a major threat to the British administrations in both Nyasaland and Northern Rhodesia. ${ }^{49}$ The geographical location of Livingstonia stations in the border region put mission doctors in an important position 
in early colonial responses to sleeping sickness. Although it did not become a major concern for the UMCA, ${ }^{50}$ initial campaigns against sleeping sickness also involved the Blantyre Mission and the Dutch Reformed Church Mission. ${ }^{51}$

The spread of sleeping sickness to British Central African territories had been feared for some time before Chisholm's diagnosis, not least because in Uganda the disease had caused hundreds of thousands of deaths in the epidemic that ravaged the Lake Victoria region between 1901 and 1905. In December 1906, Laws had informed PMO Hearsey of the presence of sleeping sickness and tsetse fly in the Congo. ${ }^{52}$ George Prentice, then stationed at Kasungu, became a key Livingstonia doctor in the debates about preventative measures. In 1907, having been asked to temporarily take on the role of MO at Fort Jameson in Northern Rhodesia, Prentice was in no doubt that the missions and government had to join forces. ${ }^{53}$ The Nyasaland medical department established an outpost for inspecting travellers from potentially infected regions in 1907. In 1909, Hardy of the Colonial Medical Service died of sleeping sickness, and fears of an epidemic prompted the additional recruitment of MOs as well as the establishment of a Sleeping Sickness Commission in 1911 (headed by Sir David Bruce) to investigate the threat in detail. ${ }^{54}$

The colonial government attempted to establish strict movement restrictions within the perceived sleeping sickness zones and to quarantine and inspect every suspected disease carrier. Those suspected of infection were to be sent to isolation camps. The implementation of these practical procedures relied upon missionary doctors to carry out inspections. Perhaps ironically, particular attention was paid to members of the Livingstonia mission community, which was viewed as harbouring a suspiciously mobile population of teachers, evangelists and pupils who frequently travelled over the border zone into the infected areas. Some of the first confirmed victims of sleeping sickness were mission teachers..$^{55}$

At first it was assumed that raised cervical glands were a sign of possible infection, with both missionaries and colonial doctors routinely examining tens of thousands of Africans by palpating their glands. By 1908 this technique had been deemed unreliable: the majority of those with enlarged glands were not infected and thus could be wrongly isolated. Gland puncture provided a more reliable diagnostic tool, but the technique was feared and resented. Initially, as Rennick notes, gland palpation focused on mission pupils and African workers employed by Europeans. As fears of an epidemic grew, the government resorted to greater force in carrying out sleeping sickness examinations, with MOs sometimes reinforced by armed police. ${ }^{56}$ But although such forcible examples of procuring a diagnosis were associated with the government 
medical service, collaboration still very much lay at the heart of successful sleeping sickness eradication initiatives. The government medical department regularly called upon mission doctors to palpate and puncture the glands of their patients, microscopically inspect blood specimens and send infected individuals to isolation camps. The acting PMO, Norris, a former Blantyre doctor, articulated the reliance on medical missionaries when he declared them as the personnel who were generally in 'the best position to undertake gland palpitation and puncture'.$^{57}$ The use of medical missionaries was all the more expedient, given that missionary doctors were believed to be more trusted than those in the employment of the government, at least by those in mission communities.

By 1910, George Prentice of the Livingstonia Mission had become a vocal critic of government tsetse and sleeping sickness policies. For Prentice, tsetse and consequently sleeping sickness depended 'entirely upon the presence of big game', which had increased as a result of government policies of game protection that had deprived Africans of their hunting rights. In his annual report for 1910, Prentice stated that each victim of sleeping sickness, or 'tsetse fever', was 'a martyr to our policy of game protection', which had also robbed the people of their lawful food supply. He was highly critical of the way the administration had forcibly removed Africans from areas that were seen as potential sleeping sickness danger zones. Whilst Prentice believed that game, tsetse and the local populations could not safely inhabit the same area, he argued that the government had foolishly 'moved the people and left the game' in at least one area. Furthermore, he held that amongst the medical profession in the Protectorate, only government doctors supported this highly erroneous official policy. In his call for reform, Prentice called upon Scottish churches to press for progressive policies against tsetse that would include the restoration of hunting rights and the establishment of a cotton industry in Central Nyasaland. Such agricultural expansion, he argued, would also provide labour for those who had been forced to migrate. Whilst Prentice believed that the Protectorate was facing 'the biggest crisis this country has ever known', he clearly also believed that harnessing missionary support was vital to persuade colonial MOs to take up the measures that he felt would prevent any new outbreak from reaching epidemic proportions. ${ }^{58}$

The debate that ensued is indicative. Prentice's views were supported by Alexander Hetherwick, head of Blantyre, who became the spokesman for the united Scottish missionaries in Scotland and held a position in the Legislative Council in Zomba. Ideas about game destruction were fiercely opposed by Governor Alfred Sharpe, however. In Britain, the Scottish churches' deputation managed to secure a Sleeping 
Sickness Commission in 1911, and one game reserve (Elephant Marsh) was abolished. Whilst Prentice was invited to provide medical facts for the Scottish churches, he was not asked to speak in Britain, allegedly because of his poor oratory skills. ${ }^{59}$

The reasons for the lack of a coordinated response seem clear. Sleeping sickness regulations, inspections and isolation measures that often resembled military campaigns provoked strong resentment from local societies. They also considerably hampered the other work of the Livingstonia missionaries. ${ }^{60}$ In the end, sleeping sickness did not materialise in Malawi to the extent that had been feared. At the outbreak of the First World War, the Sleeping Sickness Commission was withdrawn and the medical department was prepared instead for military duty. Prentice's extensive ecological and economic anti-tsetse initiatives were not adopted, although short-lived free-shooting zones were set up in 1915, which were alleged to have merely scattered the big game and spread the tsetse further. ${ }^{61}$

The story of plague responses in colonial Malawi reveals particularly interesting examples of cooperation over health issues. In December 1916, Saulos Nyirenda and Yafet Gondwe, two Livingstonia graduates and church elders from Mchenga village near Karonga, sent the following telegraph to Dr Innes of the mission: 'We are dying [in] our village investigate come immediately.' Innes went to Mchenga, where at least three children of Christian families had died suddenly. On analysing samples, he identified a plague bacillus. The administration then sent an MO, who confirmed the diagnosis in March 1917. A large-scale plague emergency ensued, comprising travel restrictions and a major rat-destruction campaign. ${ }^{62}$

Mission-educated African Christians also played an important role in informing villagers about anti-plague measures and orders. During the initial plague panic, the Livingstonia doctors were closest to the epidemic and advised concerned colonial officials. Laws assured the Resident at Karonga, for example, that steaming all letters was an unnecessary measure and instead advocated the strict control of all traffic over the Rukuru river. ${ }^{63}$ The spirit of advice and cooperation continued and in 1919 Laws sent all the kittens from the Livingstonia headquarters for rat-hunting duty in the threatened villages. ${ }^{64}$

The plague alert resulted in considerable travel restrictions in the North and West Nyasa Districts and medical certificates for both European and African travellers continued to be required for years after the initial outbreak. Livingstonia doctors Laws and Innes undertook examinations and certifications in 1917 and $1918 .{ }^{65}$ However, by early 1919, with the arrival of a government MO in Karonga, the examinations were to become the preserve of MO Arbuckle. Unsurprisingly, 
this decision prompted sharp criticism from Laws, who, robbed of his former authority, bluntly asked why the mission doctors should now be considered 'less competent' to carry out examinations and whether in the possible absence of Dr Arbuckle all monitoring of traffic in the districts would grind to a halt. ${ }^{66}$

This exchange over plague examinations highlights one area of professional contestation between colonial and missionary doctors: the question of competence and authority. Whilst the government responded quickly to missionary alerts in both sleeping sickness and plague cases, frequently it can be seen that the MOs wanted to confirm the diagnoses themselves. This, I suggest, has to be seen in the context of the development of a distinct colonial medical elite with specialist training in tropical medicine. By the early 1900s, British MOs posted to the tropics were increasingly trained at the London and Liverpool schools of tropical medicine. A key element in their training was laboratory work; particularly carrying out microscopic investigations to identify disease-causing agents. ${ }^{67}$ This emergence of specialised elite experts in tropical medicine from the metropole contributed to questioning of and increasing conflict with local experts in the colonies, such as medical missionaries, who, especially in the early years of the century, tended to rely on authority gained through prolonged residency in the same locality. Laws was a prime example of this older kind of expert on health. However, this conflict should not be over-emphasised. It should also be noted that in Malawi the younger generation of missionary doctors, including Chisholm and Prentice, also took specialist tropical medicine courses in Britain and obtained qualifications to carry out laboratory research in Africa. ${ }^{68}$

As the Nyasaland colonial medical service began to extend into areas where previously missions had dominated Western medicine and public health, contests over authority occurred, as highlighted by the debate over plague rules and the substitution of Arbuckle for Laws. In the absence of government doctors from Karonga and in the context of the war, there was no difficulty in granting Livingstonia missionaries authority to issue travel certificates on public health grounds, but as the situation began to normalise in 1919, Arbuckle seems to have wanted to assert his authority as a government MO by assuming sole responsibility for medical certification.

\section{Leprosy collaboration in the interwar era}

As elsewhere in the British Empire, leprosy relief in Malawi brought government and missions together in formal collaboration in the interwar period. The government subsidised the treatment of leprosy 
patients through modest sums and medicinal provision, while in Nyasaland the UMCA pioneered the treatment of leprosy patients. In the 1920s, the Scottish missions, Seventh Day Adventists and White Fathers also established leprosy settlements or treatment centres. ${ }^{69}$ In 1934, the government provided an annual sum of $£ 900$ to cover all mission leprosy work, plus £100 towards leprosy and hookworm drugs. Despite an admission of the inadequacy of this subsidy, it remained roughly the same into the 1940s. By 1940, about 600 leprosy patients, mostly men, were said to be resident in mission settlements. ${ }^{70}$

From 1927 onwards, the Nyasaland Medical Department began to scrutinise the use of leprosy grants. The DMS called into question the grant for the UMCA's Likoma leprosy settlement, on the grounds that most of its patients came from Portuguese territory. In the late 1930s the medical department was, in Good's words, 'staking out its professional and "turf" positions'. Whilst admitting the value of mission services for leprosy patients, medical services now sought the power to inspect mission facilities as required and to authorise grant reductions if 'approved standards' were not met. ${ }^{71}$

It has been noted that leprosy relief was specially treated in the modern British Empire, as it largely remained an uncontested area, primarily regarded as being in the preserve of missionary medicine. Colonial medical services were willing to provide funds for leprosy care to missions, and missions willingly accepted responsibility, making reference to the spiritual tradition surrounding the care of lepers that went back to Christ. Thus, for an arguably rather small outlay, government medical services in Malawi were able to rid themselves of responsibility for a major disease. In 1927 the government estimated that there were about 6,000 leprosy patients in the Protectorate, most of them cared for by missions, often at the expense of other medical work. The rationale seems clear: for the missions, leprosy collaboration was a means of demonstrating their value to, and maintaining good relations with, both the medical department specifically and the colonial government more generally. ${ }^{72}$ Leprosy was not a high-profile tropical disease, nor was it a major threat to the colonial administration, but its treatment required long-term commitment and personnel - thus, given its low public profile, the medical services were happy to 'subcontract' its treatment to the missions.

\section{Exchanges of material and information}

Tracing the exchange of medicines also provides insight into informal collaborative trends between missions and the government medical department. As noted above, vaccine lymph, despite its unreliability, 
was one of the more successful materials exchanged by government and missionary doctors, but this was just one of the many materia medica exchanged. In 1918, as the influenza pandemic spread to South-Central Africa, MOs in Northern Rhodesia sent serum for influenza 'inoculation' to missionaries at Chitambo. ${ }^{73}$ In the interwar era, the Nyasaland Medical Department supplied some missions with medicines for the treatment of yaws, bilharzia and hookworm, as well as leprosy. In 1933, leprosy drugs for the UMCA included Moogrol and Chaulmoogra oils, trichloroacetic acid and potassium iodide. ${ }^{74}$

The sharing of information and knowledge was also important in campaigns against epidemic disease, when not only missionaries, but also mission-educated Africans played a significant part in reporting disease and acting as intermediaries for government instructions. Similarly, the colonial doctors turned to their mission colleagues for information on the African population, prevalence of disease or symptoms. Thus the mission doctors played a part in the construction of a colonial medical discourse: they charted, assessed and measured health, illness and susceptibility to disease, often in areas of the Protectorate where few government doctors were posted. ${ }^{75}$ On the basis of his long experience and status, Laws became a key informant for the government on African infant mortality, birth rate and perceived changes in population during his fifty-year period in Malawi. ${ }^{76}$

Missionary doctors and nurses also informed the authorities about cases of violence and suspected poisonings that came to their attention. However, medico-legal cooperation could be problematic. In the 1910s, the government wanted to enlist mission doctors to carry out post-mortem examinations where administration doctors were not available. Whilst Laws was keen to assist the authorities whenever possible, he strongly rejected any suggestion that mission doctors should be forced to carry out post-mortem examinations and to actually exhume the bodies (practices that were viewed with suspicion by the majority of the African population). He was reassured by MO Hugh Stannus that in cases of suspected foul play, corpses would be delivered to investigating doctors - both government and missionary. ${ }^{77}$

\section{Medical education and African medical staff}

Unlike European medical staff, there was considerable mobility from missions to government medical service among African medical assistants, orderlies and probably nurses. These were the crucial 'medical middles' who enabled the expansion of both missionary and colonial medicine, and missions dominated medical training and education at least until the Second World War. 
In early colonial Malawi, the missions ran some of the most ambitious medical training schemes in Anglophone Africa, and for a while the Scottish missions in particular trained African medical middles for employment beyond the Protectorate. The more advanced Hospital Assistant training in Blantyre and Livingstonia took three or four years to complete. ${ }^{78}$ Robert Laws was especially active in this area. As a member of the Legislative Council between 1913 and 1916, Laws wanted to create a Christian, mission-trained medical profession, first for assistants, and later also for nurses and midwives. By the First World War, the three British missions all ran some form of formal medical training scheme, and issued certificates to their graduates. By 1926, the most highly trained Hospital Assistants were registered by the government; however, most African medical staff members were not. ${ }^{79}$

In contrast to this relatively organised provision, before the 1920s, the government undertook practically no formal training of subsidiary medical staff, and even in the interwar period its programmes were modest in comparison to those run by the three leading British missions. Despite their lack of early tangible success, the colonial medical services clearly sought to develop training programmes in Zomba, as is apparent from PMO Hearsey's medical report for $1919 .{ }^{80}$ By 1923 Hearsey was able to report that the majority of state rural dispensaries were run by government-trained dispensers, although their period of training was well short of the three or four years required by the missions. ${ }^{81}$ Significantly, however, all government dispensers were former mission pupils. Furthermore, their training in Zomba was largely undertaken by senior African staff (including Thomas Cheonga and Daniel Gondwe in 1928), all of whom were mission-trained men. ${ }^{82}$

In 1936, the government opened its Medical Training School in Zomba. It offered courses for medical dressers, nurses and midwives, as well as laboratory assistants and sanitary inspectors. However, the Hospital Assistants seem to have been still exclusively mission trained. The African staff employed by the government increased from 3 hospital assistants and 132 medical dressers in 1927 to 16 Hospital Assistants and 215 dressers in $1937 .{ }^{83}$

African medical middles, especially the elite Hospital Assistants, therefore should be seen as constituting a significant connecting group between missionary and colonial medicine. Some middles moved directly from mission training into government service, others worked for long periods for the missions before taking up government employment. For example, Fred Nyirenda, a Livingstonia medical graduate, worked for Livingstonia for some years before being seconded into government service during the plague emergency. It appears that Nyirenda was not at first formally recruited, but 'on loan' from the 
mission. ${ }^{84}$ However, he was to become a key worker when the government hospital in Karonga was permanently established. In 1927, upon the recommendation of the DMS, Nyirenda was registered as a 'Native Hospital Assistant' under the new Medical Practitioners Ordinance. ${ }^{85}$ By 1939 he had become a first-grade Hospital Assistant. At that point, the medical department employed one senior, nine first-grade and six junior Hospital Assistants. ${ }^{86}$

Some middles moved across East Africa, including Dan Ngurube, one of the most highly trained Hospital Assistant graduates of Livingstonia. Ngurube graduated in 1933, in 1939 was promoted to Senior Hospital Assistant, first grade, and was at the top of African staff scale in the Nyasaland Medical Department. Later, Ngurube moved to the government medical department in Tanganyika. ${ }^{87}$

For some, the move into government service was precipitated by conflict with the mission. Daniel Gondwe, the first formally trained hospital assistant of Livingstonia, lost his position because of mission objections to his polygamous marriage in the late 1910s. Discussing the case in 1920, Laws maintained that, as a polygamist, Gondwe had become permanently 'unstable'. The government had no such qualms, however: by 1924 Gondwe was listed as one of three African Hospital Assistants in the medical department. ${ }^{88}$

Missionaries wanted to keep African medical middles under control and supervision, and made this clear to the government. ${ }^{89}$ For its part, the colonial medical department did not see the mission domination of subordinate medical education as particularly problematic and was keen to employ mission-educated medical staff. The Nyasaland Medical Department offered employment for only some mission graduates. In addition to British and African staff, the government employed Indian Sub-Assistant Surgeons (SAS): their rank was between MOs and hospital assistants, and they occupied an important middle position that otherwise might have been filled by the elite of African middles. Indeed, Laws seems to have hoped that African hospital assistants would eventually replace SASs. Practicalities hindered his ambitions, however, as by the early 1930s the most advanced medical courses at Livingstonia had to be scaled down and the supply of highly trained medical middles began to decline. When the last group of Livingstonia assistants graduated in 1933, their examination and registration by the state was a well-established process. They were examined in physiology, anatomy, hygiene and pharmacology, and the DMS noted that they were the best group that had been examined to date. After 1933, higher medical training for Africans was concentrated at the Blantyre Mission main hospital..$^{90}$

Government service offered higher salaries to African medical middles than the financially struggling missions of the 1920s could. 
There is evidence that Malawian graduates had a good reputation and that they were regularly sought after by other British administrations: notably Tanganyika and the Rhodesias. The PMO of Tanganyika, for example, contacted Laws in 1925 and asked for sixteen new medical workers. Laws replied that Livingstonia needed the sanction of the Nyasaland government to be able to formally train staff for other British territories and that it could not immediately provide such numbers. ${ }^{91}$ Although these types of requests sometimes contained an offer to subsidise the training of any staff thus supplied, this was not always the case. In 1924 Laws noted dryly that the PMO in Northern Rhodesia expected rather too much in anticipating the provision of trained assistants for free. ${ }^{92}$ In the interwar era, Tanganyika, the Rhodesias and South Africa were able to provide more favourable rates of pay to Malawian assistants. In this competitive environment the Nyasaland medical services, with lower salaries and few positions, were able to hire only some mission graduates. ${ }^{93}$

By the Second World War, the training of African nurses and midwives had become a priority for both the missions and the colonial medical services. The mission midwifery training undertaken at Blantyre, Livingstonia and Mlanda (Dutch Reformed Church) was recognised by the medical service. ${ }^{94}$ The ambitious new DMS, Dr De Boer, argued that the medical department needed reorganisation, more European and African staff and other resources. He clearly wanted to take over the medical education of African male assistants and orderlies from the missions. By 1940, the government offered free medical training in Zomba (by contrast, Blantyre charged its pupils), which the Scottish missionaries regarded as a serious threat. ${ }^{95}$ De Boer planned to gradually replace the Indian SASs with African Hospital Assistants, who were cheaper agents: in 1939 the salary of one SAS (£236) covered the wages of three Hospital Assistants. ${ }^{96}$ Although de Boer's suggestions for the wide-ranging reform of the medical services were generally welcomed by the authorities in London and Zomba, after war broke out it became clear that the necessary resources would not be forthcoming, and the scheme never was to fulfil his ambitious intentions. ${ }^{97}$

\section{Private critiques, muted conflicts}

On the surface, early twentieth-century mission-government relations on issues of medicine and health appear relatively untroubled. Conflict was more apparent in other areas of policy, such as Blantyre missionaries' critique of Johnston's administration, or the debate about mission education in the aftermath of the Chilembwe Rising in 1915. Prentice's attack on the government's sleeping sickness policies was an example 
of a rare public outburst by a missionary physician. More usually, missionary criticism of government activities remained private, as the correspondence of Laws attests.

The First World War put particular pressure on mission-government cooperation. In 1917, Laws strongly criticised the administration for failing to provide a single MO for civilian duty and for absorbing mission doctors into a large medical department for the small armed force. In a similar vein, after the government and Livingstonia disagreed over payment of mission doctors' services for plague duty, Laws lambasted the administration for not valuing the services of mission doctors. Perhaps more important than money, professional respect was at stake. Furthermore, Laws questioned the quality of treatment provided to Africans in colonial military service during the war. Livingstonia hospital had received several gravely ill Africans who were discharged from service and practically left to die. For those sick African carriers who made it to the mission hospital, the government offered to pay for a maximum stay of fourteen days as an in-patient, or $£ 1$ 1s. In a letter to the Chief Secretary, Laws described how carriers were suffering from dysentery, chronic ulcers and hunger, and pointed out that a question put to the House of Commons on the subject 'would be an exceedingly awkward one for the Government here to answer' ${ }^{98}$ However, publicly, Livingstonia, which had fully cooperated with the recruitment of carriers for war service, remained silent. ${ }^{99}$

In 1940, when the British missions were alarmed by the planned reorganisation of the Nyasaland medical services by DMS De Boer, they appealed directly to the authorities in London for support. Scottish missions, in particular, feared that the government would monopolise medicine and medical education in Nyasaland and sought reassurance that there was still room for medical missions in the country. The complaints were expressed semi-officially. Mapping this process of rather subtle appeal and complaint is revealing of the caution that clearly underscored fragile interrelations between missions and state. The Church of Scotland missionaries contacted H.M. Grace, the chairman of the Conference of Missionary Societies in Great Britain, who informed the Colonial Office that the relations between the DMS and Livingstonia in particular were 'very unsatisfactory' and that there was 'a spirit of competition by Government', which made complementary medical policy very difficult. ${ }^{100}$ Grace then had an interview with Sir Jameson at the Colonial Office, from which he left satisfied with the friendly discussions they had undertaken on the subject. In a subsequent note, Grace emphasised that he had been contacted by four important societies in Nyasaland that had had difficulties with the DMS, but all their communications had been confidential. ${ }^{101}$ 
The precise details of the mission complaints remain obscure. However, it is clear that the missionaries thought that the new government medical training programme at Zomba, which offered free education and a subsistence allowance, undercut mission medical education at Blantyre. At this stage, Blantyre charged its medical students £5 per year, and its student numbers had been halved. Missionaries stated that they had not been officially informed about the Zomba training centre at all and that there had been no discussion of the co-existence of the two institutions. In the meeting at the Colonial Office, Jameson believed that missions and government could find a workable division of labour, ideally one that allowed missions to focus on the training of public health nurses and midwives, for example. ${ }^{102}$

In this contest, missions and medical service were competing above all about African 'boys' as medical students. De Boer was willing to let missions train nurses, but wanted the training of men in government hands. Jameson believed that on financial grounds it was clear that the missions could not carry out the most advanced training. ${ }^{103}$ With the benefit of hindsight it can be seen that this contest was ultimately nothing more than a storm in a teacup: De Boer's ambitious reform plans had to be shelved during the war. However, it still serves as an illustrative example that the struggle over Western medicine in Malawi was turning towards the medical services' favour. Whilst the medical services were under-resourced, by 1940 the medical missions were weak and unable to maintain a monopoly in Blantyre. De Boer found that the Blantyre mission hospital could not serve as a site for the planned government hospitals for Europeans, Africans and Asians, as its buildings 'had nearly served their period of usefulness'. However, De Boer acknowledged that the medical services had no funds or desire to expand into remote areas that were adequately served by missions. The growing town of Blantyre, in turn, had sufficient African population to justify both government and mission hospitals. ${ }^{104}$ The 1940 conflict remained largely obscure even for some of those involved. Jameson confessed that after the friendly talk with Grace, he still did not 'know the ins and outs of this matter at all' and asked de Boer for further, unofficial information. ${ }^{105}$ It seems clear in practice that to no small degree, and despite a veneer of collaboration, competition, professional jealousy and lack of contact prohibited extensive cooperation.

\section{Conclusion}

Colonial medical services and British missions in Malawi exchanged and shared information, materials and personnel. Mission-educated African medical middles provided a crucial skilled workforce for 
the expanding medical department, and material exchanges were regularly undertaken, albeit on an ad hoc rather than formal basis. Yet, despite these examples of fluidity between the two groups, they strongly retained their distinct boundaries. Geography determined mission-government relations in medicine and healthcare. The UMCA in its 'steamer parish' across Lake Malawi and Livingstonia in the north were in more remote and thus independent positions. As their network of stations, congregations and African and European medical staff extended far beyond the government's presence, collaboration with these missions enabled the administration to reach local societies. In the Shire Highlands, where colonial and missionary medicine overlapped, a division of labour was cost-effective: the mission concentrated on Blantyre and African patients, the Colonial Service on Zomba and government employees. Colonial medicine in Malawi focused more on men, particularly able-bodied government workers, soldiers and labourers. Missions treated more women, children, elderly patients (cataract operations were a particular strength of mission surgery in the early 1900s) and leprosy patients.

Missions mediated knowledge, practices and materials between the fragile colonial state and African societies. They informed the administration of local disease conditions, people's health and their views on improvement. They also helped to ensure the enactment of government regulations, orders and advice regarding illness and health, and in turn strove to influence government decision making in these fields. In the early period, some missionaries exerted quasi-official authority in enforcing health regulations, thus becoming de facto MOs. However, as colonial medical services in Nyasaland strengthened in the 1920s, the medical department took a more critical attitude towards medical missions and mission doctors, and increasingly insisted upon its hegemony over medical and public health policy, authority and practice.

By the Second World War, the medical department's professional and administrative ambition to have the final say on all publicly funded medical and health practice was most apparent in leprosy collaboration as well as in competing claims to have the monopoly in African medical education. With hindsight, if British missions and the government medical department had pooled their resources, they could have established a strong medical school for the Protectorate, but such extensive collaboration seems not to have been on the agenda, either for missions or for the government - both of whom wanted control over Africans trained in medicine and nursing in their respective institutions. For missionaries, such a wish must have had its roots in attempts to exert religious control and moral scrutiny. For the colonial 
MOs, secular professional demands for administrative hegemony probably prevented more extensive cooperation. In the end, the African population, the government and the missions were all left without an adequate number of African medical staff.

Finally, the 1940 conflict surrounding De Boer's reforms highlighted how the British missions, with their representatives in Edinburgh and London, could make their cases and take their complaints to the higher echelons of the Colonial Service, but these exchanges left only faint traces in official records. On the surface, the British missions and colonial administration seemed unified in their championing of Western medicine and public health, but underneath there were significant fractures in their cooperation.

This study of collaboration, connections and conflicts between missions and the Colonial Medical Service reminds us that Western medicine in the colonial world was not monolithic or marked by simple dualism between state and churches or secular and spiritual agents. Medical practice, practitioners, knowledge and materials were constituted, transferred and connected in complex imperial networks that included MOs, missionary physicians and various medical middles. Both cooperation and conflicts occurred within these networks, and the fuller understanding of colonial medicine in both local and imperial contexts requires sensitivity to these informal agents, exchanges and connections.

\section{Acknowledgements}

I would like to thank Anna Greenwood, Ryan Johnson and Liz Eastcott for their invaluable help in improving this chapter (all omissions or errors are naturally my own). The research has been made possible thanks to funding from the Academy of Finland (project no. 121514) and the Department of History and Ethnology, University of Jyväskylä.

\section{Notes}

1 Megan Vaughan, Curing Their Ills: Colonial Power and African Illness, Cambridge, Polity Press, 1991, p. 56

2 Charles Good, The Steamer Parish: The Rise and Fall of Missionary Medicine on an African Frontier, London, University of Chicago Press, 2004, p. 278

3 For an overview of the history of Western medicine in Malawi, see Michael King and Elspeth King, The Story of Medicine and Disease in Malawi: The 150 Years Since Livingstone, Blantyre, The Montfort Press, 1997. On missionary medicine, see Good, The Steamer Parish; Markku Hokkanen, Medicine and Scottish Missionaries in the Northern Malawi Region: Quests for Health in a Colonial Society, Lewiston, The Edwin Mellen Press, 2007; Agnes Rennick, 'Church and Medicine: The Role of Medical Missionaries in Malawi 1875-1914', unpublished $\mathrm{PhD}$ thesis, University of Stirling, 2003; Vaughan, Curing Their Ills. On Colonial 


\section{BEYOND THE STATE}

Medical Service, see Colin Baker, 'The Government Medical Service in Malawi', Medical History, 20, 3, 1976, pp. 296-311

4 Vaughan, Curing Their Ills; Rennick, 'Church and Medicine'; Hokkanen, Medicine and Scottish Missionaries

5 There were other Catholic and Protestant missions in Malawi practising medicine, but in the colonial period the three main British missions were predominant

6 Baker, 'The Government Medical Service'

7 Good, The Steamer Parish

8 Michael Worboys, 'The Colonial World as Mission and Mandate: Leprosy and Empire, 1900-1940', Osiris, 15, 2000, pp. 207-18

9 For Livingstonia, see John McCracken, Politics and Christianity in Malawi: The Impact of the Livingstonia Mission in the Northern Province, Blantyre, CLAIM, 2000; Hokkanen, Medicine and Scottish Missionaries

10 Good, The Steamer Parish; Rennick, 'Church and Medicine'

11 Rennick, 'Church and Medicine', p. 37; McCracken, Politics and Christianity, pp. 147-9, 212; Hokkanen, Medicine and Scottish Missionaries, pp. 73-4, 77-8, 156

12 Ronald Oliver, The Missionary Factor in East Africa, London, Longmans, 1952, pp. 109-28; Colin Baker, 'The Development of the Administration to 1897', in Bridglal Pachai (ed.), The Early History of Malawi, London, Northwestern University Press, 1972

13 Rennick, 'Church and Medicine', p. 46; Andrew C. Ross, Blantyre Mission and the Making of Modern Malawi, Blantyre, CLAIM, 1996

14 McCracken, Politics and Christianity, pp. 147-9

15 Baker, 'The Government Medical Service', pp. 296-8; King and King, The Story of Medicine, pp. 90, 103

16 Rennick, 'Church and Medicine', p. 317

17 Rennick, 'Church and Medicine', pp. 328-30

18 The National Archives, UK (TNA) CO/626/19 Nyasaland Protectorate Administration Reports 1939, Annual Report of the Social and Economic Progress of the People of Nyasaland for the Year 1939, p. 7; Nyasaland Protectorate, Annual Medical Report for 1914, Zomba, 1915; Nyasaland Protectorate, Annual Medical Report for 1928, Zomba, 1929

19 Good, The Steamer Parish; Hokkanen, Medicine and Scottish Missionaries; Rennick, 'Church and Medicine'

20 Rennick, 'Church and Medicine', pp. 338-9

21 Rennick, 'Church and Medicine', p. 338; Hokkanen, Medicine and Scottish Missionaries

22 Rennick, 'Church and Medicine', pp. 124-6, 232-8

23 Vaughan, Curing Their Ills, pp. 100-1, 107-10; Megan Vaughan, 'Idioms of Madness: Zomba Lunatic Asylum, Nyasaland, in the Colonial Period', Journal of Southern African Studies, 9, 2, 1983, pp. 218-38, at 218-21

24 Baker, 'The Government Medical Service', pp. 301-4

25 TNA CO/626/19 Nyasaland Protectorate Administration Reports 1939, Annual Report of the Social and Economic Progress of the People of Nyasaland for the Year 1939 , p. 4

26 TNA CO/626/5, Nyasaland Protectorate Proceedings (Minutes) of the Executive Council 1920-1925, Minutes of the Executive Council, 18 December 1923

27 Malawi National Archives (MNA) 47/LIM/1/24 Letterbook of Laws, 1924-1925, letters 266 and 310, Laws to Fraser, 3 and 18 March 1925

28 Vaughan, Curing Their Ills, p. 23

29 For the benefits of a colonial medical career see Anna Crozier, Practising Colonial Medicine: The Colonial Medical Service in East Africa, London, I.B. Tauris, 2007, pp. $46-71$

30 Hokkanen, Medicine and Scottish Missionaries, pp. 365-6

31 Rennick, 'Church and Medicine', pp. 151, 238-9

32 TNA CO/525/184/14, De Boer to Chief Secretary, 31 July 1940

33 Baker, 'The Government Medical Service', p. 307; The Registration of 


\section{BRITISH MISSIONS IN COLONIAL MALAWI}

Medical Practitioners Ordinance, No. 9 of 1906, [? British Central Africa Gazette, 1906]

34 TNA CO/626/8, Nyasaland Executive Council Minutes, 1926-1930, Minutes of the Executive Council, 8 September 1927; King and King, The Story of Medicine, pp. 136-7. For the rising, see George Shepperson and Thomas Price, Independent African, Edinburgh, Edinburgh University Press, 1958; John McCracken, A History of Malawi, Woodbridge, James Currey, 2012, pp. 127-46

35 TNA CO/525/184/14, De Boer to Chief Secretary, 31 July 1940

36 Vaughan, Curing Their Ills, p. 23

37 John Lwanda, 'Politics, Culture and Medicine in Malawi: Historical Continuities and Ruptures with Special Reference to HIV/AIDS', unpublished PhD thesis, University of Edinburgh, 2002, p. 76

38 Good, The Steamer Parish, pp. 238-40; Eugenia W. Herbert, 'Smallpox Inoculation in Africa', Journal of African History, 16, 4, 1975, pp. 539-59; Lwanda, 'Politics, Culture and Medicine', pp. 65-7

39 Hokkanen, Medicine and Scottish Missionaries, p. 146; Rennick, 'Church and Medicine', p. 297

40 Hokkanen, Medicine and Scottish Missionaries, pp. 146, 298; Rennick, 'Church and Medicine', p. 302

41 Rennick, 'Church and Medicine', pp. 297-300

42 Good, The Steamer Parish, p. 274

43 Rennick, 'Church and Medicine', pp. 301-2; TNA CO/626/6, Nyasaland Protectorate Legislative Council Minutes, 1908-1925, Summary of the Proceedings of the Legislative Council of Nyasaland, 2nd session, 5 to 7 November 1908

44 Annual Medical Report, 31 December 1913, quoted in Rennick, 'Church and Medicine', p. 301

45 Free Church of Scotland Monthly Record, January 1901, pp. 17-19; Hokkanen, Medicine and Scottish Missionaries, pp. 353-4

46 Rennick, 'Church and Medicine', p. 302

47 MNA 47/LIM/1/1/9, Overtoun Institution Letterbook 1906-1908, letters 172 and 17, Laws to Hearsey, 2 December 1906, enclosure from Laws to Hearsey, no date; Hokkanen, Medicine and Scottish Missionaries, p. 482

48 Good, The Steamer Parish, pp. 380-2

49 Hokkanen, Medicine and Scottish Missionaries, pp. 484-6

50 Good, The Steamer Parish, p. 251

51 Rennick, 'Church and Medicine', pp. 307-10

52 MNA 47/LIM/1/1/9, Overtoun Institution Letterbook 1906-1908, letters 172 and 17, Laws to Hearsey, 2 December 1906

53 National Library of Scotland, Edinburgh (NLS) Acc/7548/D71, Letters to the Livingstonia Sub-Committee 1907, p. 71, Prentice, 9 May 1907

54 Baker, 'The Government Medical Service', pp. 298-9

55 The Livingstonia News, October 1909, p. 65; Nyasaland Protectorate, Report of Commissioner for 1912-1913, Cmd. 7050, London, 1913, pp. 22-3; Hokkanen, Medicine and Scottish Missionaries, p. 485

56 Rennick, 'Church and Medicine', pp. 308-10

57 MNA 50/BMC/2/1/96, Norris to Hetherwick, 2 December 1908, quoted in Rennick, 'Church and Medicine', p. 310

58 Annual Report of the Livingstonia Mission for 1910, Glasgow, 1911, pp. 27-9

59 Rennick, 'Church and Medicine', pp. 312-6

60 Hokkanen, Medicine and Scottish Missionaries, p. 486

61 Baker, 'The Government Medical Service', p. 300; Good, The Steamer Parish, pp. 250-1; Hokkanen, Medicine and Scottish Missionaries, p. 486; John McCracken, 'Experts and Expertise in Colonial Malawi', African Affairs, 81, 1982, pp. 101-16, at p. 107. For a comparable case of co-operation during the plague emergency in Accra, see Ryan Johnson, 'Mantsemei, Interpreters and the Successful Eradication of Plague: The 1908 Plague Epidemic in Colonial Accra', in Ryan Johnson and Amna 


\section{BEYOND THE STATE}

Khalid (eds.), Public Health in the British Empire: Intermediaries, Subordinates, and the Practice of Public Health, 1850-1960, New York, Routledge, 2012

62 MNA 47/LIM/1/1/17, Laws to Resident, Karonga, 18 December 1916; Hokkanen, Medicine and Scottish Missionaries, pp. 488-9

63 MNA 47/LIM/1/1/17, letters 853 and 906, Laws to MacDonald, 19 February and 14 March 1917; Hokkanen, Medicine and Scottish Missionaries, pp. 489-90

64 MNA 47/LIM/1/19, Overtoun Institution Letterbook 1919-1921, letter 292, Laws to Hearsey, 16 October 1919. On rat eradication campaigns, see Vaughan, Curing Their Ills, pp. 39-43

65 Hokkanen, Medicine and Scottish Missionaries, pp. 488-92

66 MNA 47/LIM/1/1/19, Overtoun Institution Letterbook 1919-1921, letter 79, Laws to Arbuckle, 21 May 1919

67 Deborah Neill, Networks in Tropical Medicine: Internationalism, Colonialism, and the Rise of a Medical Speciality 1890-1930, Stanford, Stanford University Press, 2012, pp. 60-5

68 Hokkanen, Medicine and Scottish Missionaries

69 Good, The Steamer Parish, pp. 337-9; Worboys, 'The Colonial World'

70 Good, The Steamer Parish, pp. 337-42

71 Good, The Steamer Parish, p. 342

72 Good, The Steamer Parish, pp. 337-40; Worboys, 'The Colonial World'

73 MNA 47/LIM/1/1/35, Moffatt to Laws, 6 December 1918

74 Good, The Steamer Parish, p. 337, p. 341

75 For Malawi, see Hokkanen, Medicine and the Scottish Missionaries, p. 497. For collaboration within the wider Empire, see Ryan Johnson and Amna Khalid (eds.), Public Health in the British Empire: Intermediaries, Subordinates, and the Practice of Public Health, New York and London, Routledge, 2012

76 MNA 47/LIM/1/1/25a, Letterbook of Laws, 1925-1927, Laws to Superintendent of Census, 31 January 1925

77 Hokkanen, Medicine and Scottish Missionaries, pp. 497-8

78 Good, The Steamer Parish; Hokkanen, Medicine and Scottish Missionaries; Rennick, 'Church and Medicine'

79 Hokkanen, Medicine and Scottish Missionaries, pp. 414-18; King and King, The Story of Medicine, pp. 132-6

80 Nyasaland Protectorate, Annual Medical Report for 1919, Zomba, 1920

81 Nyasaland Protectorate, Annual Medical Report for 1923, Zomba, 1924

82 Nyasaland Protectorate, Annual Medical Report for 1928, Zomba, 1929, pp. 6, 23

83 King and King, The Story of Medicine, p. 136

84 MNA 47/LIM/1/19, Overtoun Institution Letterbook 1919-1921, letter 597, Laws to Innes, 28 April 1920. For a broader picture, see Johnson and Khalid (eds.), Public Health in the British Empire

85 TNA CO/626/8, Nyasaland Executive Council Minutes, 1926-1930, Minutes of the Executive Council, 19 August 1927

86 TNA CO/626/19, Nyasaland Protectorate Administration Reports, 1939, Annual Medical Report for 1939. Although Nyirenda and four others passed the Senior Hospital Assistant examination, only one (Dan Ngurube) was promoted in 1939

87 TNA CO/626/19, Nyasaland Protectorate Administration Reports, 1939, Annual Medical Report for 1939

88 Hokkanen, Medicine and Scottish Missionaries, pp. 415, 417; Nyasaland Protectorate, Annual Medical Report for 1924, Zomba, 1925, p. 17; Nyasaland Protectorate, Annual Medical Report for 1930, Zomba, 1931; King and King, The Story of Medicine, p. 133

89 Hokkanen, Medicine and Scottish Missionaries, pp. 414-18

90 Hokkanen, Medicine and Scottish Missionaries, pp. 420-1

91 NLS MS/7888, letter 98, Niven to Laws, 17 June 1925; MNA 47/LIM/1/1/25a, Letterbook of Laws 1925-1927, letter 45, Laws to Niven, no date

92 MNA 47/LIM/1/1/24, Letterbook of Laws, 1924-1925, letter 46, Laws to Chisholm, 4 November 1924 


\section{BRITISH MISSIONS IN COLONIAL MALAWI}

93 TNA CO/525/178/1, Minute of E.S. Boyd, 14 August 1939

94 TNA CO/626/19, Nyasaland Protectorate Administration Reports, 1939, Annual Report of the Social and Economic Progress of the People of Nyasaland for the Year 1939 , p. 6

95 TNA CO/525/184/14, De Boer to Chief Secretary, 31 July 1940; Note of a talk with the Rev. H.M. Grace, 21 October 1940

96 TNA CO/525/177/17, Hall to the Under Secretary of State, Colonial Office, 15 August 1939

97 TNA CO/525/178/1, Minute of E.S. Boyd, 14 August 1939

98 MNA 47/LIM/1/1/14, Laws to Acting Chief Secretary, 2 August 1917; Hokkanen, Medicine and Scottish Missionaries, pp. 500-2

99 McCracken, Politics and Christianity, pp. 269-70; Hokkanen, Medicine and Scottish Missionaries, p. 502

100 TNA CO/525/184/14, Grace to the Under Secretary of State, Colonial Office, 16 September 1940

101 TNA CO/525/184/14, Grace to Sir Wilson Jameson, 22 October 1940

102 TNA CO/525/184/14, Note of a talk with the Rev. H.M. Grace, 21 October 1940

103 TNA CO/525/184/14, Jameson to De Boer, 22 October 1940

104 TNA CO/525/184/14, De Boer to Chief Secretary, 31 July 1940

105 TNA CO/525/184/14, Jameson to De Boer, 22 October 1940 